he was appointed Disney professor of archæology at Cambridge, concurrently with his museum work; and it was with this double experience that he entered on his professorship of classical art and archæology at Oxford in 1887. Since 1880, too, he had been one of the original editors of the Journal of Hellenic Studies, and responsible for the high standard of scholarship and wide scope at which it aimed.

Classical archæology was in its infancy in 1887 as an academic subject in Oxford. Gardner's only predecessor, Sir William M. Ramsay, had been interested in exploration and in epigraphy, and had spent much of his time in travel. There were valuable collections, the 'Arundel Marbles' and the like from seventeenth century patrons of learning; and the new Keeper of the Ashmolean Museum, Sir Arthur Evans, was accumulating new materials in classical as well as prehistoric archæology. But there were few books, no casts or place for housing them; for a disastrous bargain had glutted the University Galleries with replicas of the works of Sir Francis Chantrey. But even before the reorganization of the Ashmolean Museum, and as part of a comprehensive plan, originals were installed, casts were acquired, and a modest work-shed was provided. Gardner's own conviction, bred of museum experience, and illustrated by his monumental "Numismatic Commentary on Pausanias" (1887), that in ancient coins we have a compendious and inexhaustible series of miniature illustrations of all aspects of Greek art, as well as of religious belief and local tradition, gave him initial advantage in planning his academic programme under such conditions, and in dealing with such early pupils as Sir George Hill and Dr. J. G. Milne. The breadth of Gardner's interests at this time is illus. trated by his share in a collaborated "Manual of Greek Antiquities" (1892) ; his judgment and critical taste by his "Catalogue of the Ashmolean Vases" (1895) and "Sculptured Tombs of Hellas" (1896), and his deep philosophıc interest in æsthetic problems by his "Grammar of Greek Art" (1905). As pupils became more numerous, systematic publication was less frequent, especially since there was no departmental staff, and only occasional lectures by college tutors supplemented the professor's own teaching. For many years, Gardner did the work of a college tutor for all his men, as well as his own. But he was a frequent contributor to the Numismatic Chronicle and the Journal of Hellenic Studies, and remained an editor of the latter until 1926.

It was during this later period too, from the publica. tion of "Exploratio Evangelica" in 1899, that he allowed himself to give expression to his profound interest in the critical and historical aspects of early Christianity, in regard to which he combined what were then advanced liberal views with a simple reverence and personal piety which commended his scholarship and philosophical outlook to a wider circle of readers. From 1915 until 1923 he was president of the Modern Churchmen's Union, and remained an intimate and trusted counsellor of theologians of many schools. Though he took little public part in university business, he was a convinced advocate of research as an essential of university training, and of facilities for it after graduation; and his "Oxford at the Cross Roads" (1903) expressed frankly and strongly what only a few of his colleagues had then begun to envisage elearly, still less to advocate or practise.

In 1925 Gardner retired as emeritus professor, but continued for some years to publish, and even, on occasion, to lecture; combining in his "Principles of Christian Art" his two dominant interests. In 1934 a slender volume of "Autobiographica" unveiled much that only intimate friends appreciated or suspected, of his devotion to scientific truth, to the interpretation of beauty in men's handiwork, and to the realization of his own high standard of living.

J. L. M.

\section{Dr. A. H. Church, F.R.S.}

Dr. EDith Phirip Smith, of the Department of Botany, University College, Dundee, writes as follows :

As an old student of A. H. Church, I should like to add a few words of appreciation and recollection to the obituary notice appearing in NATURE of May 22.

No one who has not had the privilege of studying under Church can fully appreciate the manner of man he was. To his students he was an unfailing (but not an uncritical) friend. No slip-shod or incomplete work was tolerated : everything had to be done to a finish, in which he set an example by his unremitting application to his own research. But it was his dispassionate accuracy and integrity of purpose which created the deepest impression.

Church was an inspired teacher. The condensed and often cryptic English of his writings (which has prevented their full appreciation) became clear and enthralling when expanded in lecture or tutorial.

Church's writings have not yet taken the place they deserve in botanical literature, partly on account of their difficult style, and partly because they were all in advance of their time. The "Types of Floral Mechanism", for example, contains the prolegomena to a serious theory of the flower, which has scarcely been assimilated after twenty-nine years. I was told by Church that he had the remaining material of his projected study of the flower completed, but that the expense of publication was prohibitive. I do not know whether any project is on foot for a memorial to Church at Oxford, but I can think of no more appropriate tribute to his memory than to assist in the publication of his floral studies (if they still exist).

\section{WE regret to announce the following deaths :}

Sir Edward Davson, Bart., K.C.M.G., an authority on Colonial trade and Imperial economics and a trustee of the Imperial Institute, on August 7, aged sixty-two years.

Sir David Masson, K.B.E., F.R.S., emeritus professor of chemistry in the University of Melbourne, aged seventy-nine years.

Prof. F. C. S. Schiller, emeritus professor of philosophy in the University of California, on August 6, aged seventy-three years. 